\title{
Study of Physiochemical Properties of Local Wheat Cultivars and Their Effect on White Layer Cake Quality
}

\author{
Shano Abdulrahman Omer \\ Biotechnology and Crop Science \\ College of Agricultural Engineering Science \\ University of Sulaimani \\ Sulaimani, Iraq \\ Shano.omer@univsul.edu.iq
}

\author{
Dlir Amin Saber \\ Food Science \& Quality Control \\ College of Agricultural Engineering Science \\ University of Sulaimani \\ Sulaimani, Iraq \\ Dlir.sabir@univsul.edu.iq
}

Volume 4-Issue 2

December 2019

DOI:

10.24017/science.2019

.2 .17

Received:

03 November 2019

Accepted:

20 December 2019

\begin{abstract}
Physiochemical and rheological properties of local wheat cultivars were studied to determine and develop their relationship to baking quality of white layer cake. The investigation carried out via studying four different wheat cultivars (Adana, Sham 6, Tamooz 2, and Slemani 2), and comparing to a locally produced flour (from Sulaimani Cereal Milling Company) as control. According to physical parameters the highest value were obtained by Slemani 2, and in terms of falling number control also recorded the highest. In regards to chemical composition (such as; Protein, Fat, Ash, and Moisture) the greatest values were reported by (Tamooz 2, Sham 6, Adana, and Slemani 2) respectively. Nevertheless, rheological characteristics for farinograph in terms of (water absorption, developing time, stability, and tolerance mixing index), the highest values were achieved by (Tamooz 2, Adana, Control, and Sham 6), respectively. While for amylograph characteristics the highest values were recorded in Slemani 2, and Control in terms of (pasting temperature, and peak viscosity) respectively. The gluten yield parameters tested for gluten index, and dry gluten in which the results obtained for Control, and Sham 6 were the greatest. For physical characteristics of the white layer cake the Control achieved the highest value for volume index, symmetry index, and specific volume. Finally, the Control and Adana have scored the highest values for sensory evaluation. In general, the best white layer cake quality was obtained from the Control, Adana, and Sham 6 , hence the protein quality and quantity have great influence on the end product.
\end{abstract}


Keywords: Wheat cultivar, Rheology, Physico-chemical, Sensory evaluation, Gluten Index ,and White layer cake.

\section{INTRODUCTION}

Wheat is the major food and principal crop and can grow almost anywhere on the earth and different weather conditions i.e. hard weather status. It is also grown on the different types of soils due to adaptability characteristics. [1].The most important physiochemical properties in wheat quality is grain hardness. The wheat quality is also based on various factors such as environmental fluctuating, type, and genetic nature. The environmental condition has a major effect on the quality and quantity of the wheat proteins, and protein quantities influenced by the nitrogenous fertilizers according to research [2].Wheat flour dough was the most attracted dough structure by the authors for further investigation due to its unique viscoelastic behavior in forming a dough which is from the wheat protein characteristics $[3,4]$.

Many studies have reported on the rheology of wheat flour constituents such as gluten which is considered as the most important factor to produce elasticity in the wheat flour dough[5]. Extensive studies performed by [4, 6, 7]on the dough components (gluten, starch, lipid and water content) in the mixture to investigate the dough rheological behavior. Whereas the rheological evaluation has been utilized to study the flour quality and other parameters like elasticity and viscosity of the dough are also considered as valued factors in the flour quality measurement [8].The previously named rheological factors are always critical in the bakery marketing and production because it is helping the producers to have the overall idea about the end-use of flour. The rheological properties are also important in specifying the ingredients, quality control and stabilizers to input in the elaborated products which also have a direct effect on its processing and end-use quality[9].

Further, the dough rheological measurement is used to determine its physical properties. The principal purpose of the rheological measurement is to gain the quantitative determination of the materials, to increase knowledge about the construction and molecular structure of the material, it is also useful to characterize and figure the material's performance also for quality control [10]. Rheological estimations are an important tool to help in prepare control and handle plans[11].Numerous rheological tests are used to foretell the end product quality such as mixing behavior, sheeting, and heating execution [12].Dough rheology can greatly affect the potential of the wheat flour, to produce maximum results of dough preparation chemical analysis has been explored. Due to the complicated biological, the production can make lack of understanding[13]. Wheat cultivars have different physiochemical and rheological characteristics which are the ability of materials to regain the original shape, and directly influence the quality of the wheat product like bread, and biscuits [14].

Hard wheat flour is qualified by having high protein content (gluten) which is used for bread making and cakes, durum wheat semolina for making pasta products. A lower protein content flour or soft wheat is used principally for crackers, cookies, cakes and breakfast cereals. Having differences in the kernel hardness and also which product is produced from them is refer to the gluten content of them[15].

The purpose of this study was to characterize the fundamental rheological properties of dough from different wheat cultivars. Also, to evaluate the quality of wheat cultivars and differentiate between them, and to predict the contraction of the dough after processing, and also sensory evaluation of white layer cake from different locally wheat flour cultivars.

\subsection{Materials}

\section{METHODSAND MATERIAL}

Four locally available wheat cultivars were obtained from Bakrajo Agricultural Research Center (Adana, Sham 6, Tammoz 2, and Slemani 2) in Sulaimani, Kurdistan Region, Iraq, then compare with flour from Sulaimani Cereal Milling Company as Control. 


\subsection{Milling}

The wheat grains were milled through Universal mill Instruments, (Inc.DE-200g, stainless steel, $1200 \mathrm{w}$ ) home electronic miller to obtain flour.

\subsection{Physical Analysis}

The hectoliter weight of wheat grain was determined by an approved method of the American Association of Cereal Chemists AACC Method No. 55-10.01[16], thousand kernel weight was obtained by counting 1000 grains of wheat and then weighing them (in grams),and the falling number was determined by using an approved method of AACC Method 56-81.04[17].

\subsection{Proximate chemical Analysis}

The following methods were used for wheat flour chemical analysis. AACC Method 44-01.01 Calculation of Percent Moisture for rapid estimation of moisture content[18]. AACC Method No. 8-21.01 Prediction of Ash content in Wheat Flour-Near -Infrared Method, it is probably that (NIR) calibrations are associated with cellulosic components of bran fractions in the flour[19]. AACC Method 30-10.01 Crude Fat in Flour, Bread, and Baked Cereal Products[20].AACC method No. 39-11.01 Near-Infrared Reflectance method for protein determination in wheat flour[21]. The proximate total carbohydrate content was calculated by difference according to AOAC[22].

\subsection{Rheological properties}

Rheological tests were evaluated by using Farinograph-E instrument (Brabender, Germany)following standard method of AACC Method 54-21.02 by mixing $300 \mathrm{~g}$ of wheat flour with water on $14 \%$ moisture basis which was added as the dough was mixed to a consistency of $500 \mathrm{BU}$, while the amount of water needed to produce the $500 \mathrm{BU}$ dough consistency was clarified as the water absorption percentage[23]. Moreover, an Amylograph test was performed by using $60 \mathrm{~g}$ of flour mixed with $450 \mathrm{ml}$ of distilled water according to AACC Method 61-01[24].

\subsection{Gluten Yield and Gluten Index}

\subsubsection{Gluten Index}

The gluten index was determined according to standard methods of AACC 38-12.02[25]. The gluten index yield was calculated by the given formula below:

Glutenindex $=\frac{\text { weightof } \text { wet gluten } \text { remained }}{\text { weightof } \text { wet gluten }} \times 100$.............(1)

\subsubsection{Dry Gluten Yield}

Dry gluten yield was determined by drying the total amount of the wet gluten at $150 \mathrm{C}^{0}$ for 4 min following formula:

Dry gluten yield $=\frac{\text { weightofdryglutenobtained } \times 860}{100-\% \text { sample moisture }}$

\subsection{White layer cake procedure}

The product was prepared with some modification in the method given for cake preparation in AACC Method 10-90.01[26],with 200g flour, 280g sugar, shortening 100g, 24g non-fat dry milk,120g egg whites, $6.0 \mathrm{~g}$ salt, $7.0 \mathrm{~g}$ baking powder, and $250 \mathrm{ml}$ water. And the cake was baked at $175{ }^{\circ} \mathrm{C}$ for $40 \mathrm{~min}$. And the following formulas were determined:

\subsubsection{Volume Index}

The volume index was determined by carefully cutting the cake vertically through the center to two equal pieces and important measurements were made for one piece according to AACC Method 10-91.01[27].

Volumeindex $=B+C+D$ 


\subsubsection{Uniformity Index}

Uniformity Index $=B-D$

while B, C, and D means the diameters of the cake as illustrated in the figure below:

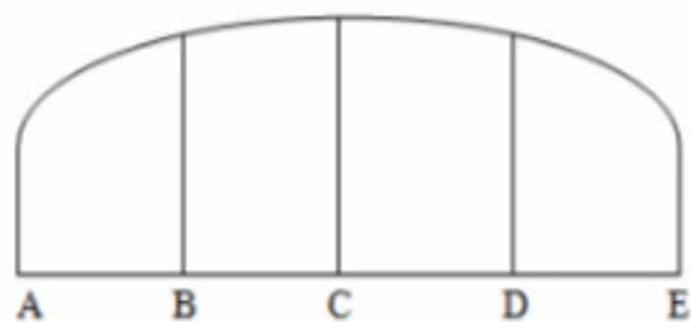

Figure 1: Physical indices of the cake

\subsubsection{Shrinkage value}

Shrinkage value is the diameter of cakes measured from (A to E) to the nearest $0.1 \mathrm{~cm}$ then subtract the diameter from $20.3 \mathrm{~cm}$ (pan diameter).

Shrinkage $=20.3$-(diameter of the cut section of cake)

\subsubsection{Evaluation of Cake}

The cake was evaluated for its weight, volume, and weight to volume ratio. Cake volume was determined by rapeseed displacement according to standard methods of AACC 10-05.01[28]. Specific weight was calculated by the given formula below:

SpecificCakeVolume: $=\frac{\text { cakevolume }(\mathrm{cm} 3)}{\text { cake } \operatorname{weight}(g)}$

\subsection{Sensory evaluation of white layer cake}

White layer cake made from different wheat cultivars flour were evaluated according to the method described by AACC method, the cake samples were left at room temperature to cool for one hour, after that the cake was cut with an electronic knife and situated to the panel test, with the following degrees: Cells with 30 degrees include (uniformity 10, size of cells 10, and the thickness of the walls 10 ), grain 16 , texture 34 (moistness 10 , tenderness 14 , and softness 10 ), crumb color 10 , flavor 10 , and overall 100 degrees.

\subsection{Statistical analysis}

The results were finalized in triplicates and expressed by means except for the determinations. Statistical significance was done using Analysis of Variance (ANOVA) models to calculate the studied parameters. The significance of differences was evaluated according to Duncan's multiple range analysis which was carried out using XLSTAT software.

\subsection{Physical analysis}

\section{RESULTS AND DISCUSSION}

The data included in table 1 is presenting the physical parameters of wheat kernel which showed that there was a significant difference among all cultivars in terms of thousand kernel weight, moisture content, and hectoliter. The Slemani 2 cultivar was reached the highest values, while for falling number Control was the greatest among all cultivars. Thousand kernel weight is controlled by gene however, the environment may influence these parameters[29]. Similar results was obtained for Sham 6 cultivar in term of thousand kernel weight[30]. 
Hectoliter is considered as an important factor which can result in increasing the wheat seed yield because values over $78 \mathrm{~kg} / \mathrm{hl}$ may increase the commercial production[31]. The falling number above 400 seconds showed that flour is lacking in alpha-amylase and the flour should supplement with amylase to obtain desirable enzyme activity level[32].

Table1:Physical parameters of wheat grain.

\begin{tabular}{lcccc}
\hline Cultivars & $\begin{array}{c}\text { Thousand } \\
\text { Kernel weight } \\
\mathbf{( g )}\end{array}$ & $\begin{array}{c}\text { Kernel Moisture } \\
\text { content (\%) }\end{array}$ & $\begin{array}{c}\text { Hectoliter } \\
\mathbf{( k g / h l )}\end{array}$ & $\begin{array}{c}\text { Falling } \\
\text { No. (sec) }\end{array}$ \\
\hline Control & $41.17 \mathrm{bc}$ & $8.16 \mathrm{~b}$ & $78.13 \mathrm{~b}$ & 665 \\
\hline Slemani 2 & $47.46 \mathrm{a}$ & $8.33 \mathrm{a}$ & $81.46 \mathrm{a}$ & 446 \\
\hline Adana & $41.95 \mathrm{~b}$ & $7.93 \mathrm{c}$ & $77.80 \mathrm{c}$ & 600 \\
\hline Sham 6 & $32.48 \mathrm{~d}$ & $8.00 \mathrm{c}$ & $76.33 \mathrm{~d}$ & 565 \\
\hline Tamooz 2 & $40.31 \mathrm{c}$ & $7.43 \mathrm{~d}$ & $74.83 \mathrm{e}$ & 554 \\
\hline
\end{tabular}

\subsection{Proximate chemical analysis}

Data in table 2 indicates that there were significant differences for chemical composition among all cultivars in terms of ( Protein, Fat, Carbohydrate, Moisture, and Ash), which they reached the highest values for ( Tamooz 2, Sham 6, Adana, Slemani 2, and Adana) were (13.2\%, 2.18\%, 77.55\%, 8.16\%, and 2.48\%) respectively. The low moisture content of wheat or flour is stable during the storage, higher moisture content higher than (14.5\%) can lead to attracting insect, molds, and bacteria[33], the wheat protein maintains a great contribution to the rheological characteristics of the wheat flour dough[34]. The broad range in protein content in the results from wheat cultivars suggest that there were flours for various applications, involving cakes and biscuits (lowest values), and whole bread. While wheat cultivars with the lowest content of ash is containing higher amounts of endosperm and eventually produce more flour[33].

Different wheat cultivar had different values of fat content this may be as a result of climatic factors at growth and genetic differences of wheat cultivars [34]. Furthermore, variation in fat content among wheat cultivars may due to the way they are milled, despite making a small amount of the wheat flour weight fat can have a great influence of the dough properties, at lower concentrations, fat can restrict starch granules swelling, decrease protein extractability and reduce the product's volume, also at higher concentrations, they can increase volume through gas cells stabilization[35].

Table2: Proximate chemical composition of flours from different wheat cultivars.

\begin{tabular}{lccccc}
\hline Cultivars & Moisture (\%) & Protein (\%) & Fat (\%) & Ash (\%) & Total Carbohydrate (\%) \\
\hline Control & $7.83 \mathrm{~b}$ & $12.03 \mathrm{c}$ & $1.13 \mathrm{e}$ & $2.02 \mathrm{~b}$ & $76.98 \mathrm{~b}$ \\
\hline Slemani 2 & $8.16 \mathrm{a}$ & $11.80 \mathrm{~d}$ & $2.00 \mathrm{~b}$ & $1.70 \mathrm{c}$ & $76.33 \mathrm{c}$ \\
\hline Adana & $7.56 \mathrm{~d}$ & $10.63 \mathrm{e}$ & $1.76 \mathrm{~d}$ & $2.48 \mathrm{a}$ & $77.55 \mathrm{a}$ \\
\hline Sham 6 & $7.70 \mathrm{c}$ & $12.33 \mathrm{~b}$ & $2.18 \mathrm{a}$ & $2.32 \mathrm{a}$ & $75.46 \mathrm{~d}$ \\
\hline Tamooz 2 & $7.30 \mathrm{e}$ & $13.20 \mathrm{a}$ & $1.89 \mathrm{c}$ & $1.93 \mathrm{~b}$ & $75.67 \mathrm{~d}$ \\
\hline
\end{tabular}




\subsection{Rheological properties \\ 3.3.1 Farinograph Test}

Data in table 3 for rheological characteristics of wheat cultivars indicated that there were significant differences between them in terms of farinograph parameter for (Water absorption, Developing time, Stability, Tolerance Mixing Index, Time to Break, and Farinograph quality number) which they reached the highest values for ( Tamooz 2, Adana, Control, Sham 6, Adana, and Adana) were (87.3\%, 4.36, 13.0, 306.66, 4.76,and 47.66) respectively. [36] showed that wheat flour having a high content of protein and starch damage has more water absorption value than those flours which have lower protein content and damaged starch, [34] stated that different wheat cultivars have different developing time, and it is affected by the quantity and the concentration of the wheat protein. Also [37] reported that the wheat cultivars are varying in dough stability.

Table 3: Farinograph results of wheat cultivars.

\begin{tabular}{lcccccc}
\hline Cultivars & $\begin{array}{c}\text { Water } \\
\text { absorption } \\
\text { \% }\end{array}$ & $\begin{array}{c}\text { Developing } \\
\text { time Min. }\end{array}$ & $\begin{array}{c}\text { Stability } \\
\text { Min. }\end{array}$ & $\begin{array}{c}\text { Tolerance } \\
\text { Mixing } \\
\text { index FU }\end{array}$ & $\begin{array}{c}\text { Time to } \\
\text { break } \\
\text { Min. }\end{array}$ & $\begin{array}{c}\text { Farinograph } \\
\text { quality } \\
\text { number } \\
\text { degree }\end{array}$ \\
\hline Control & $73.06 \mathrm{c}$ & $2.40 \mathrm{~d}$ & $13.00 \mathrm{a}$ & $53.66 \mathrm{c}$ & $3.83 \mathrm{~b}$ & $38.33 \mathrm{bc}$ \\
\hline Slemani 2 & $85.33 \mathrm{ab}$ & $3.06 \mathrm{c}$ & $1.33 \mathrm{~b}$ & $238.66 \mathrm{~b}$ & $3.53 \mathrm{~b}$ & $35.33 \mathrm{bc}$ \\
\hline Adana & $86.36 \mathrm{a}$ & $4.36 \mathrm{a}$ & $2.33 \mathrm{~b}$ & $241.66 \mathrm{~b}$ & $4.76 \mathrm{a}$ & $47.66 \mathrm{a}$ \\
\hline Sham 6 & $83.80 \mathrm{~b}$ & $3.30 \mathrm{bc}$ & $1.30 \mathrm{~b}$ & $306.66 \mathrm{a}$ & $3.73 \mathrm{~b}$ & $34.66 \mathrm{c}$ \\
\hline Tamooz 2 & $87.30 \mathrm{a}$ & $3.73 \mathrm{~b}$ & $1.66 \mathrm{~b}$ & $243.66 \mathrm{~b}$ & $4.00 \mathrm{~b}$ & $40.00 \mathrm{~b}$ \\
\hline
\end{tabular}

\subsubsection{Amylograph Test}

According to table 4 and figure 2 for amylographic characteristics the results are showing that the pasting temperature was ranged between $\left(63-87 C^{0}\right)$ for Control, and Slemani 2 respectively, while the peak viscosity was ranged between (200-420 AU) for Slemani 2, Sham 6 , and Control, in case of the peak viscosity temperature was about $90 \mathrm{C}^{0}$ for all cultivars.

The results also showing that the similarity between Tamooz 2, and the Control for peak viscosity, and peak viscosity temperature, while there is a similarity between Sham 6, Adana, and Slemani 2 in terms of pasting temperature. From the previous studies indicate that differences in peak viscosity of flours of different wheat cultivars were as a result of differences in amylase activity, and also the whole flour's peak viscosity is influenced by nature and wheat cultivar [38].

Table 4: Amylograph properties of different wheat cultivars

\begin{tabular}{lccc}
\hline Cultivars & $\begin{array}{c}\text { Pasting Temperature } \\
\mathbf{C}^{\mathbf{0}}\end{array}$ & Peak Viscosity AU & $\begin{array}{c}\text { Peak Viscosity Temperature } \\
\mathbf{C}^{\mathbf{0}}\end{array}$ \\
\hline Control & 63 & 420 & 92 \\
\hline Slemani 2 & 87 & 200 & 90 \\
\hline Adana & 81 & 230 & 90 \\
\hline Sham 6 & 81 & 200 & 90 \\
\hline Tamooz 2 & 73 & 230 & 93 \\
\hline
\end{tabular}




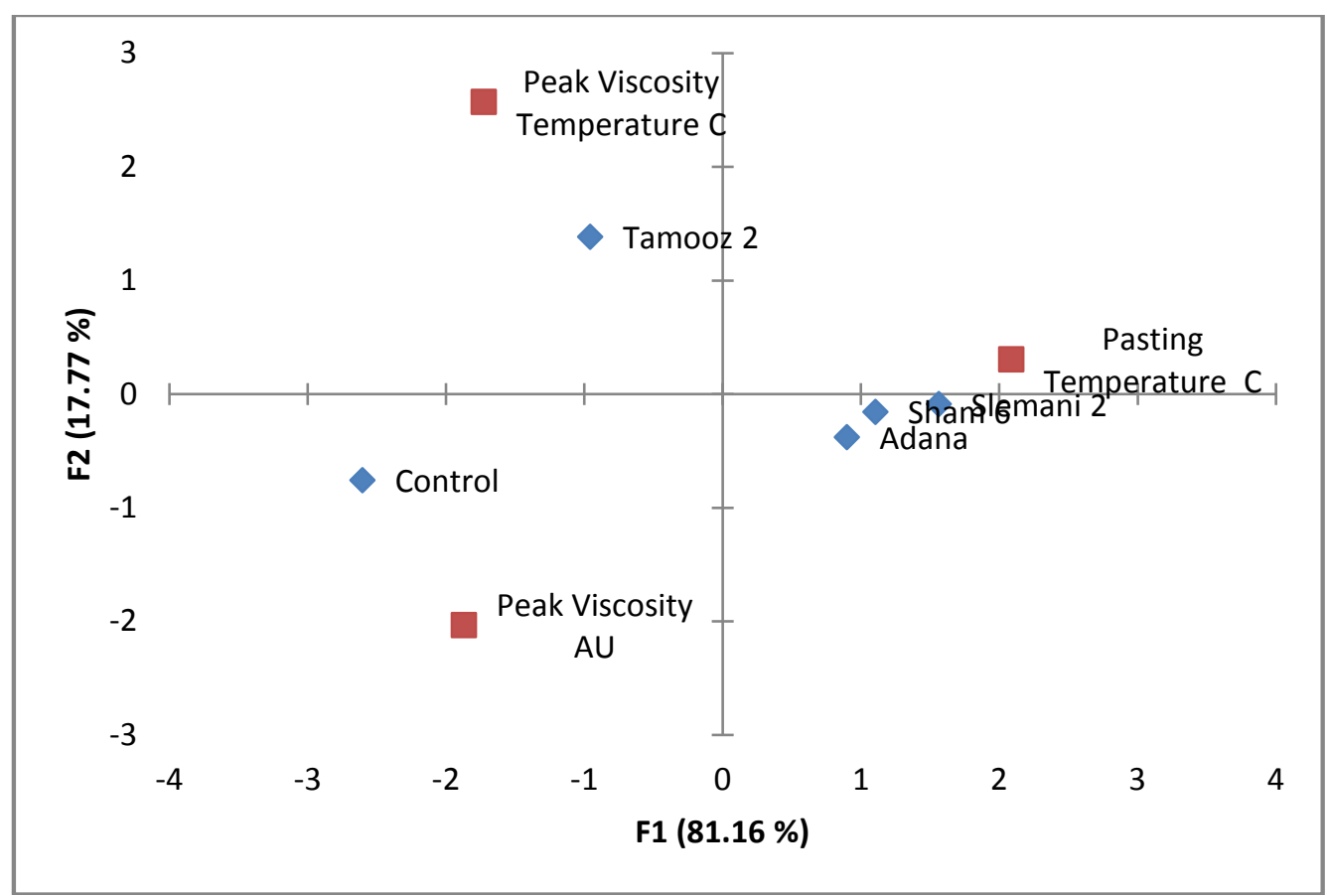

Figure 2: PCA of amylograph properties of wheat cultivars

\subsection{Gluten yield}

According to the determination of the gluten yield for wheat cultivars which is presented in table 4 and figure 3, in terms of (Weak gluten, Total Gluten, Gluten Index, and Dry Gluten), the highest values recorded for ( Slemani 2, Sham 6, Control, and Sham 6) which were (23.6, 27.6, 93, and 8.9) respectively.

Also, the results are showing the similarity between the Control, and Adana in terms of the Gluten Index. While there were similarities between Sham 6 and Tamooz 2 in terms of Weak Gluten, Total Gluten, and Dry Gluten. It is clear that the gluten index is a good indicator of the wheat flour quality which means the higher the gluten index the better end-product quality[39].

Table 4: The determination of gluten yield of wheat cultivars.

\begin{tabular}{lcccc}
\hline Cultivars & $\begin{array}{c}\text { Weak Gluten } \\
\mathbf{( \% )}\end{array}$ & $\begin{array}{c}\text { Total Gluten } \\
\mathbf{( \% )}\end{array}$ & $\begin{array}{c}\text { Gluten Index } \\
\mathbf{( \% )}\end{array}$ & $\begin{array}{c}\text { Dry Gluten } \\
\mathbf{( \% )}\end{array}$ \\
\hline Control & 1.6 & 24 & 93 & 8.5 \\
\hline Slemani 2 & 23.6 & 24.3 & 2.8 & 8.2 \\
\hline Adana & 2.1 & 23.8 & 91.1 & 8 \\
\hline Sham 6 & 16 & 27.6 & 42 & 8.9 \\
\hline Tamooz 2 & 17.9 & 26.3 & 31.9 & 8.6 \\
\hline
\end{tabular}




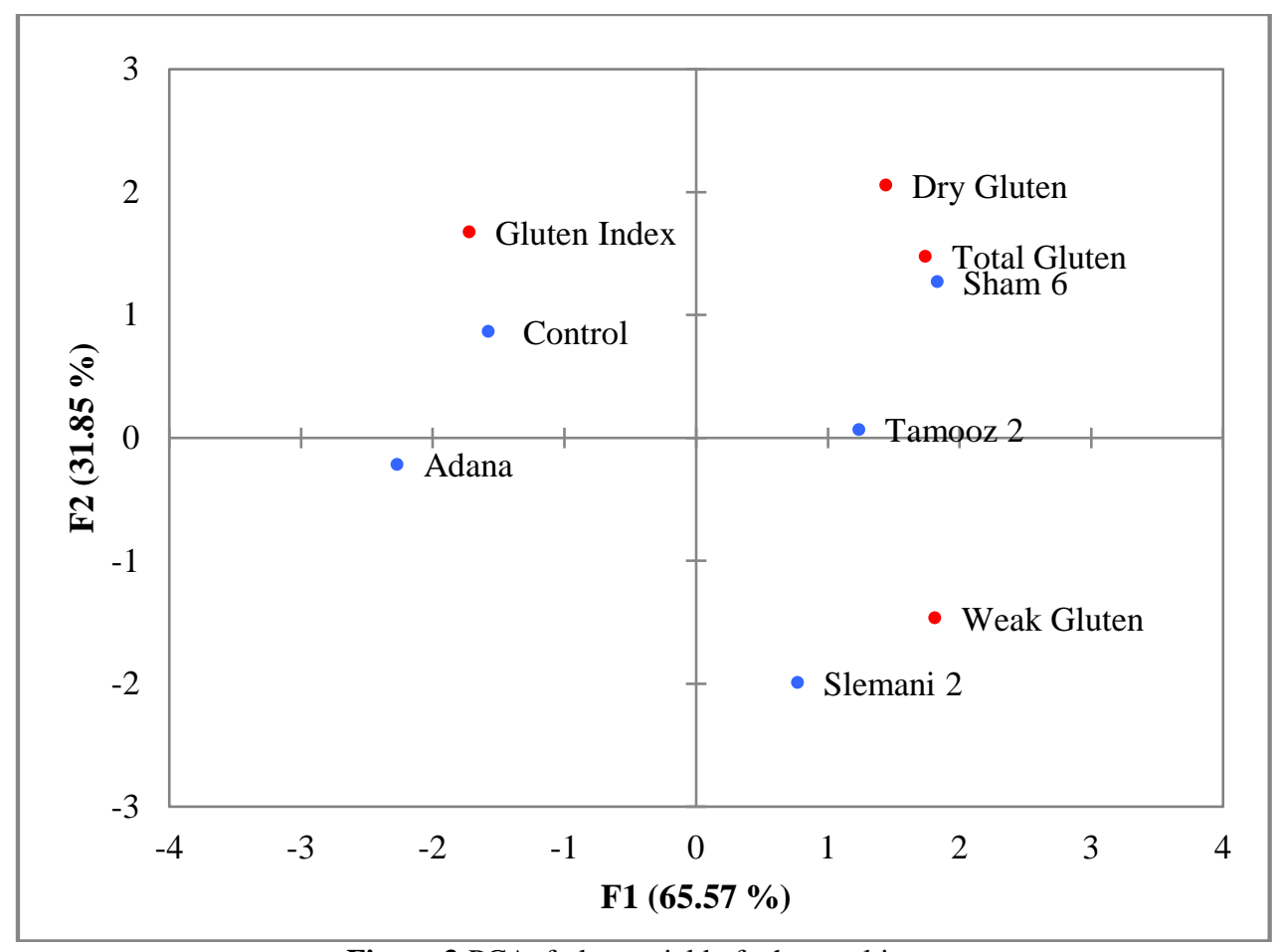

Figure 3:PCAof gluten yield of wheat cultivars

\subsection{White layer cake}

Data in table 5 for physical characteristics of white layer cake indicates that there were a significant differences between all cultivars for (Volume Index, Symmetry Index, Uniformity Index, Shrinkage value, and Specific Volume) which have obtained ( 8.83, 1.36, 0.8, 1.1, and 1.72) for (Control, Control, Adana\& Sham 6, Slemani 2, and Control) respectively. Also[40] has reported that the index parameters and characteristics give only a concept about the cake volume.

Table 5:Physical characteristics of white layer cake

\begin{tabular}{lccccc}
\hline Cultivars & $\begin{array}{c}\text { Volume } \\
\text { Index }(\mathbf{c m})\end{array}$ & $\begin{array}{c}\text { Symmetry } \\
\text { Index }(\mathbf{c m})\end{array}$ & $\begin{array}{c}\text { Uniformity } \\
\text { Index }(\mathbf{c m})\end{array}$ & $\begin{array}{c}\text { Shrinkage } \\
\text { value (cm) }\end{array}$ & $\begin{array}{c}\text { Specific } \\
\text { volume }\left(\mathbf{c m}^{3} / \mathbf{g}\right)\end{array}$ \\
\hline Control & $8.83 \mathrm{a}$ & $1.36 \mathrm{a}$ & $0.43 \mathrm{a}$ & $0.23 \mathrm{c}$ & $1.72 \mathrm{a}$ \\
\hline Slemani 2 & $6.43 \mathrm{c}$ & $0.06 \mathrm{~b}$ & $0.73 \mathrm{a}$ & $1.10 \mathrm{a}$ & $1.43 \mathrm{a}$ \\
\hline Adana & $7.20 \mathrm{bc}$ & $0.60 \mathrm{~b}$ & $0.80 \mathrm{a}$ & $0.56 \mathrm{bc}$ & $1.68 \mathrm{a}$ \\
\hline Sham 6 & $7.93 \mathrm{~b}$ & $0.66 \mathrm{~b}$ & $0.80 \mathrm{a}$ & $0.46 \mathrm{c}$ & $1.55 \mathrm{a}$ \\
\hline Tamooz 2 & $6.93 \mathrm{c}$ & $0.56 \mathrm{~b}$ & $0.43 \mathrm{a}$ & $0.96 \mathrm{ab}$ & $1.05 \mathrm{~b}$ \\
\hline
\end{tabular}

\subsection{Sensory evaluation of white layer cake}

According to the results in table 6 for sensory evaluation of white layer cake indicated that there were significant differences between wheat cultivars in terms of ( Uniformity, Size of cells, Thickness of walls, Moistness, Tenderness, Softness, Grain, Crumb color, and Flavor) which reached from the highest for Control (5.6, 9.6, 9.6, 10.0, 13.6, 9.6, 9.6, and 91), to the lowest for Slemani 2 ( 3.0, 4.6, 2.3, 5.3, 8.0, 7.0, 9.0, 3.3, 9.0, and 51) respectively. Figure 3 presented the white layer cake samples made with different cultivars of wheat. 
Table 6: Sensory evaluation of white layer cake with different wheat cultivars.

\begin{tabular}{|c|c|c|c|c|c|c|c|c|c|c|}
\hline 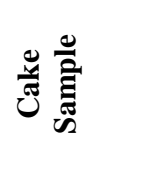 & 률율 & 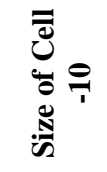 & 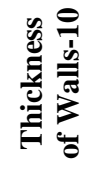 & 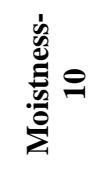 & 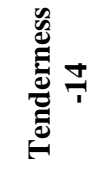 & 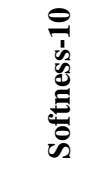 & 兄 & 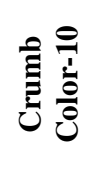 & $\begin{array}{l}\text { 음 } \\
\frac{1}{0} \\
\frac{1}{1} \\
\frac{1}{1}\end{array}$ & 矛 \\
\hline Control & $5.66 \mathrm{a}$ & $9.66 a$ & $9.66 a$ & $10.00 \mathrm{a}$ & $13.66 a$ & $9.66 a$ & $13.66 a$ & $9.66 a$ & $9.66 a$ & $91.00 \mathrm{a}$ \\
\hline Slemani2 & $5.00 \mathrm{a}$ & $5.66 \mathrm{~cd}$ & $2.33 c$ & $5.33 c$ & 8.33c & $7.00 \mathrm{c}$ & $9.00 \mathrm{~b}$ & $3.33 c$ & $9.00 \mathrm{a}$ & $54.98 b$ \\
\hline Adana & $5.00 \mathrm{a}$ & $7.66 \mathrm{~b}$ & $9.66 a$ & 9.66ab & $1.33 \mathrm{~b}$ & 7.66bc & $15.00 \mathrm{a}$ & 7.33b & $9.00 \mathrm{a}$ & 82.33a \\
\hline Sham 6 & $3.00 \mathrm{~b}$ & $7.00 \mathrm{bc}$ & $9.66 a$ & 9.33ab & $11.00 \mathrm{~b}$ & 8.66ab & 14.33a & $7.66 \mathrm{~b}$ & 9.66a & 80.33a \\
\hline Tamooz2 & 5.33a & $4.66 \mathrm{~d}$ & $5.00 \mathrm{~b}$ & $8.66 b$ & $8.00 \mathrm{c}$ & $7.66 \mathrm{bc}$ & $9.33 b$ & $3.66 \mathrm{c}$ & $9.00 \mathrm{a}$ & $61.33 \mathrm{~b}$ \\
\hline
\end{tabular}

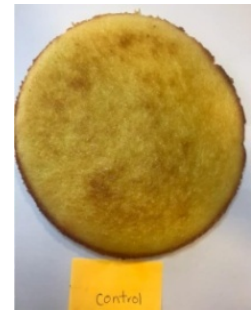

(A)

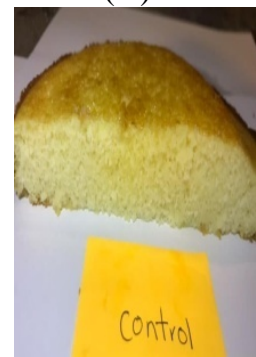

(A)

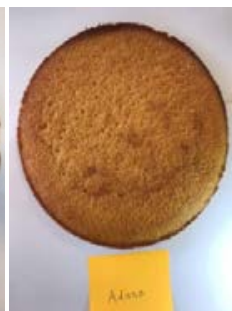

(B)

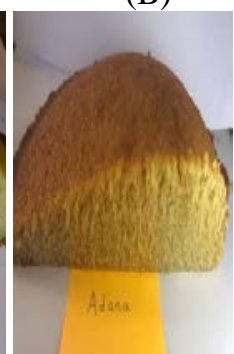

(B)

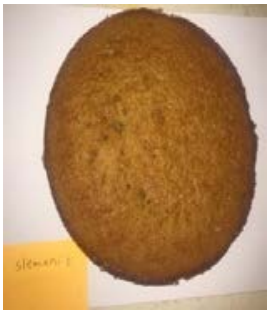

(C)

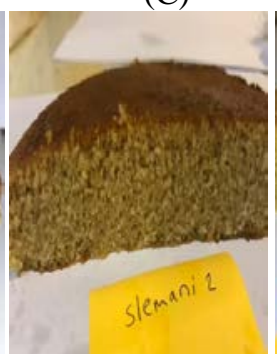

(C)

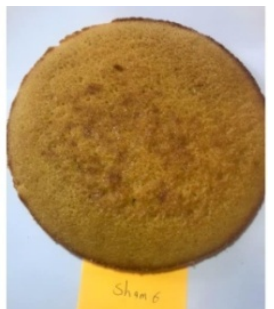

(D)

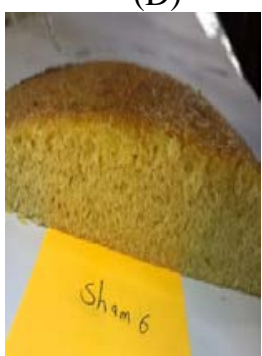

(D)

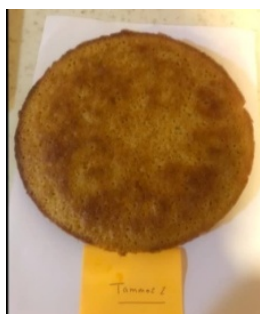

(E)

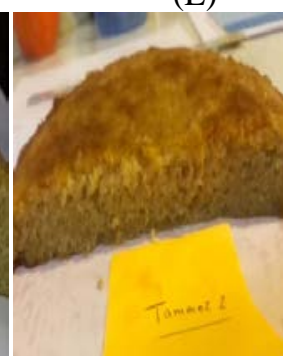

(E)

Figure 3: Physical appearance and layers of cake made with different cultivars (A) Cake made with Control flour, (B) Cake made with Adana cultivar, (C) Cake made with Slemani 2 cultivar, (D) Cake made with Sham 6 cultivar, and (E) Cake made with Tamooz 2 cultivar.

\section{CONCLUSION}

There are significant differences among all cultivars in terms of physiochemical, rheological, gluten yield, physical characteristics, and sensory evaluations. Adana and Sham 6 have the best values among the tested cultivars in terms of sensory evaluation as compared to the Control. The general conclusion achieved from the literature review and the results obtained from the laboratory tests are showing that the best quality cultivars are those that produce low protein flour hence to make a cake with good quality in terms of uniformity, softness, grain, and size of cells. This report also concluded that the Control reached the best cake quality because it consists of mixing with wheat cultivars. The recommendation for future study is to mix more cultivars for achieving the best cake quality.

\section{REFERENCE}

[1] A. Kamal, M. Islam, B. Chowdhry, and M. M. Talukder, "Yield performance and grain quality of wheat varieties grown under rainfed and irrigated conditions," Asian J. Plant Sci, vol. 2, pp. 358-360, 2003.

[2] P. Randall and H. Moss, "Some effects of temperature regime during grain filling on wheat quality," Australian journal of agricultural research, vol. 41, pp. 603-617, 1990. 
[3] A. Bloksma, "Dough structure, dough rheology and baking quality," Cereals Food World, 2, 35, 237-244, 1990.

[4] A. S. Szczesniak, J. Loh, and W. R. Mannell, "Effect of moisture transfer on dynamic viscoelastic parameters of wheat flour/water systems," Journal of Rheology, vol. 27, pp. 537-556, 1983.

[5] P. Dreese, J. Faubion, and R. Hoseney, "Dynamic rheological properties of flour, gluten, and gluten-starch doughs. I. Temperature-dependent changes during heating," Cereal Chem, vol. 65, pp. 348-353, 1988.

[6] M. Dubois, "New offerings in rheology," Developments in food science, 1983.

[7] A. C. Eliasson, T. G. Carlson, and K. Larsson, "Some effects of starch lipids on the thermal and rheological properties of wheat starch," Starch-Stärke, vol. 33, pp. 130-134, 1981.

[8] M. Ognean, C. F. Ognean, and A. Bucur, "Rheological effects of some xylanase on doughs from high and low extraction flours," Procedia Food Science, vol. 1, pp. 308-314, 2011.

[9] J. Samaan, G. H. El-Khayat, F. A. Manthey, M. P. Fuller, and C. S. Brennan, "Durum wheat quality: II. The relationship of kernel physicochemical composition to semolina quality and end product utilisation," International journal of food science \& technology, vol. 41, pp. 47-55, 2006.

[10] B. Dobraszczyk and M. Morgenstern, "Rheology and the breadmaking process," Journal of cereal Science, vol. 38, pp. 229-245, 2003.

[11] G. Scott and P. Richardson, "The application of computational fluid dynamics in the food industry," Trends in Food Science \& Technology, vol. 8, pp. 119-124, 1997.

[12] B. J. Dobraszczyk, "The physics of baking: rheological and polymer molecular structure-function relationships in breadmaking," Journal of Non-Newtonian Fluid Mechanics, vol. 124, pp. 61-69, 2004.

[13] M. R. Amjid, A. Shehzad, S. Hussain, M. A. Shabbir, M. R. Khan, and M. Shoaib, "A comprehensive review on wheat flour dough rheology," Pakistan Journal of Food Sciences, vol. 23, pp. 105-123, 2013.

[14] C. E. Stathopoulos, A. A. Tsiami, J. D. Schofield, and B. J. Dobraszczyk, "Effect of heat on rheology, surface hydrophobicity and molecular weight distribution of glutens extracted from flours with different bread-making quality," Journal of Cereal Science, vol. 47, pp. 134-143, 2008.

[15] E. Marconi and M. Carcea, "Pasta from non traditional raw materials," 2001.

[16] AACC Approved Methods of Analysis, 11 ${ }^{\text {th }}$ Ed. Method55-10.01. Physical Tests. Cereals \& Grains Association, St. Paul, MN, U.S.A, 2000.

[17] AACC Approved Methods of Analysis, $11^{\text {th }}$ Ed. Method 56-81.04. Determination of Falling Number. Cereals \& Grains Association, St. Paul, MN, U.S.A, 2000.

[18] AACC Approved Methods of Analysis, $11^{\text {th }}$ Ed. Method 44-01.01. Calculation of Percent Moisture. Cereals \& Grains Association, St. Paul, MN, U.S.A, 2000.

[19] AACC Approved Methods of Analysis, $11^{\text {th }}$ Ed. Method 8-21.01. Prediction of Ash Content in Wheat FlourNear Infrared Method. Cereals \& Grains Association, St. Paul, MN, U.S.A, 2000

[20] AACC Approved Methods of Analysis, $11^{\text {th }}$ Ed. Method 0-10.01. Crude Fat in Flour, Bread, and Baked Cereal Products. Cereals \& Grains Association, St. Paul, MN, U.S.A, 2000.

[21] AACC Approved Methods of Analysis, $11^{\text {th }}$ Ed. Method 39-11.01.Near-Infrared Reflectance Method for Protein Determination. Cereals \& Grains Association, St. Paul, MN, U.S.A, 2000.

[22] AOAC Official Methods of Analysis, $15^{\text {th }}$ Ed. Method 932.06, 925.09, 985.29, 923.03. Association of Official Analytical Chemists. Arlington, VA, U.S.A, 1990.

[23] AACC Approved Methods of Analysis, 11 $11^{\text {th }}$ Ed. Method 54-21.02. Rheological Behavior of Flour by Farinograph. Cereals \& Grains Association, St. Paul, MN, U.S.A, 2000.

[24] AACC Approved Methods of Analysis, $11^{\text {th }}$ Ed. Method 61-01. Rheological Behavior of Flour by Amylograph. Cereals \& Grains Association, St. Paul, MN, U.S.A, 2000.

[25] AACC Approved Methods of Analysis, $11^{\text {th }}$ Ed. Method 38-12.02. Determination of Wheat Gluten, Dry Gluten, Water Binding Capacity, and Gluten Index. Cereals \& Grains Association, St. Paul, MN, U.S.A, 2000.

[26] AACC Approved Methods of Analysis, $11^{\text {th }}$ Ed. Method 10-90.01. Baking Quality of Cake Flour. Cereals \& Grains Association, St. Paul, MN, U.S.A, 2000.

[27] AACC Approved Methods of Analysis, $11^{\text {th }}$ Ed. Method 10-91.01.Use of Layer Cake Measuring Template. Cereals \& Grains Association, St. Paul, MN, U.S.A, 2000.

[28] AACC Approved Methods of Analysis, $11^{\text {th }}$ Ed. Method 10-05.01. Guidelines for Measurement of Volume by Rapeseed Displacement. Cereals \& Grains Association, St. Paul, MN, U.S.A, 2000.

[29] P. Willams, F. J. El-Haramein, H. Nakkaoul, and S. Rihawi, "Crop Quality Evaluation Methods and Gudilines," ed: ICARDA, 1986

[30] A. Al-Saleh and C. S. Brennan, "Bread wheat quality: some physical, chemical and rheological characteristics of Syrian and English bread wheat samples," Foods, vol. 1, pp. 3-17, 2012.

[31] G. G. Piccinin, A. L. Braccini, L. G. Dan, C. A. Scapim, T. T. Ricci, and G. L. Bazo, "Efficiency of seed inoculation with Azospirillum brasilense on agronomic characteristics and yield of wheat," Industrial Crops and Products, vol. 43, pp. 393-397, 2013.

[32] S. P. Cauvain and L. S. Young, "Technology of breadmaking," 2007.

[33] H. Keran, M. Salkić, A. Odobašić, M. Jašić, N. Ahmetović, and I. Šestan, "The importance of determination of some physical-chemical properties of wheat and flour," Agriculturae Conspectus Scientificus, vol. 74, pp. 197200, 2009.

[34] Z. Iqbal, I. Pasha, M. Abrar, S. Masih, and M. S. Hanif, "PHYSICO-CHEMICAL, FUNCTIONAL AND RHEOLOGICAL PROPERTIES OF WHEAT VARIETIES," Journal of Agricultural Research (03681157), vol. 53, 2015. 
[35] H. Goesaert, K. Brijs, W. Veraverbeke, C. Courtin, K. Gebruers, and J. Delcour, "Wheat flour constituents: how they impact bread quality, and how to impact their functionality," Trends in food science \& technology, vol. 16, pp. 12-30, 2005.

[36] H. Yamamoto, S. T. Worthington, G. Hou, and P. Ng, "Rheological properties and baking qualities of selected soft wheats grown in the United States," Cereal chemistry (USA), 1996.

[37] A. Mahmood, "Acid-page gliadin composition and cluster analysis for quality traits of different wheat varieties," university of agriculture, faisalabad, 2004.

[38] M. I. Siddique, "physico-chemical properties of composite flours for chapati roducation," University of Agriculture Faisalabad Pakistan, 1989.

[39] N. L. Kent and A. Evers, Technology of cereals: an introduction for students of food science and agriculture: Woodhead Publishing, 1994.

[40] M. O. Raeker and L. A. Johnson, "A micro method for cake baking (high ratio, white layer)," Cereal chemistry, 1995. 